\title{
The Influence of BYOD Concept on Development of Learning Process in Universities
}

\section{La influencia del concepto BYOD en el desarrollo del proceso de aprendizaje en las universidades}

\author{
Antonina Pavlovna Sokolova \\ Russian State University of Tourism and Service, Moscow, Russia \\ https://orcid.org/0000-0002-2840-9591 \\ Liliya Yur'evna Gromova \\ Moscow State pedagogical University (MSPU), Moscow, Russia \\ https://orcid.org/0000-0002-5654-2496 \\ Irina Victorovna Tekucheva \\ Moscow State pedagogical University (MSPU), Moscow, Russia \\ https://orcid.org/0000-0002-1176-3789 \\ Ludmila Borisovna Kocherevskaya \\ Moscow Aviation Institute (National Research University), Moscow, Russia \\ https://orcid.org/0000-0002-1928-5005 \\ Elena Grigorievna Dmitrieva \\ RUDN University, Moscow, Russia \\ https://orcid.org/0000-0002-1723-7181
}

Received 09-08-20 Revised 10-10-20

Accepted 20-12-21 On line 03-17-21

*Correspondence

Email: sokolova.a.p@bk.ru

(C) Universidad San Ignacio de Loyola, Vicerrectorado de Investigación, 2021 


\section{Summary}

Education is one of the largest markets promoting implementation of Bring Your Own Device BYOD. The BYOD model was originated in colleges and universities, being stimulated by technologically advanced students, who demanded it, and administrators of educational entities, who agreed that allowance to get access to the network using personal devices was a competitive advantage. Nowadays this concept attracts great attention. People depend on their personal devices and want to have the opportunity to use them anywhere in order to make their life simpler and more efficient. While BYOD implementation increases, teachers determine new methods of integration of mobile devices into learning. The use of personal mobile devices of students for learning seems to be attractive for universities, since these devices would help to reduce expenses and to support teaching and learning. The research objective: to detect the level of influence of BYOD concept on learning process. In the conclsuoins authors confirm that BYOD is the dominant model in universities.

Keywords: Mobile Device, Personal Device, Network Access Control, Students.

\section{Resumen}

La educación es uno de los mercados más grandes que promueve la implementación de Bring Your Own Device BYOD. El modelo BYOD se originó en colegios y universidades, siendo estimulado por estudiantes tecnológicamente avanzados, que lo demandaban, y administradores de entidades educativas, quienes coincidieron en que la concesión para acceder a la red mediante dispositivos personales era una ventaja competitiva. Hoy en día este concepto atrae una gran atención. Las personas dependen de sus dispositivos personales y quieren tener la oportunidad de usarlos en cualquier lugar para hacer su vida más simple y eficiente. Mientras aumenta la implementación de BYOD, los maestros determinan nuevos métodos de integración de dispositivos móviles en el aprendizaje. El uso de dispositivos móviles personales de los estudiantes para el aprendizaje parece ser atractivo para las universidades, ya que estos dispositivos ayudarían a reducir los gastos y apoyar la enseñanza y el aprendizaje. El objetivo de la investigación: detectar el nivel de influencia del concepto BYOD en el proceso de aprendizaje. En las conclusiones, los autores confirman que BYOD es el modelo dominante en las universidades.

Palabras clave: Dispositivo móvil, Dispositivo personal, Control de acceso a la red, Estudiantes.

\section{Introduction}

The BYOD strategy was proposed by Malcolm Harkins, Chief information security officer at Intel Corporation, in 2009. When noticing that most employees bring their own smartphones, tablets and mobile storage devices to work, instead of worrying about security loss of corporate data and employees' efficiency, he proposed the policy aimed at covering this trend and using it as a tool to reduce expenses and to increase efficiency (Johnson: 2012; Gasparian et al.: 2020).

According to G. Thomson (2012), BYOD is a concept that allows employees to use their own technologies, devices to be online, to get access to data or to execute tasks for their companies. At minimum, BYOD programs allow employees to get access to services and/or data provided by employer on their own personal tablets, e-readers, smartphones and other devices (French et al., 2014). 
In universities, BYOD became a part of students' life used everywhere: from hostels to classrooms and laboratories; at present, it is used in new environments developed for online education and mutual activities (Adhikari et al., 2012; Ivanova et al., 2020; Kinash et al., 2012).

In higher education, the opportunity to transfer information technologies to students revolutionizes their education (Lundin et al.: 2010; Ramazanova et al.: 2020). This also allows to use the technologies in classrooms in an innovative way, substituting conventional lectures, textbooks and even tests with new interactive models. BYOD, facilitating this transformation, also creates new problems and issues for IT departments, which are currently required for provision and support of BYOD (Parsons, Adhikar, 2016; Zueva et al., 2020).

According to (Sánchez et al., 2020), most students of colleges and universities (86\%) have notebooks as a main tool for academic purposes, though, in 2019 even more students than previously had tablets (15\%), smartphones (62\%) and/or e-readers (12\%). This research reflects clearly perfectly wide distribution of BYOD in education.

\section{Literature review}

According to (Adhikari et al., 2016), more and more students enter universities with personal mobile devices, such as smartphones, iPads and notebooks, which are routine tools of students, being the first choice for access to Internet as well as communications, mass media and software. As stated by forecasts, the number of personal mobile devices will increase (Cristol, Gimbert, 2013) and be used as an additional means of education.

Currently (Efremov et al., 2020) the wide use of mobile devices among students is considered as an unprecedented opportunity to apply them for teaching and learning (Cochrane et al., 2014). Contrary to the conventional policy, which relies on universities providing technologies for students (Burns, Lohenry, 2010), mobile devices allow universities to implement BYOD programs (Kobus et al., 2013). More specifically, mobile devices of students are used for support of learning activities in classrooms and outside (Golubeva et al., 2020; Dyganova, Yavgildina, 2020).

Potentials of BYOD implementation could promote development of mobile learning concept and distribution of BYOD practice in the sphere of higher education. Table 1 summarizes the main ideas of BYOD proposed by various authors.

Table (1): Main ideas of BYOD

\begin{tabular}{|l|l|}
\hline $\begin{array}{l}\text { Author } \\
\text { (reference) }\end{array}$ & Main ideas \\
\hline $\begin{array}{l}\text { R. Afreen } \\
\text { (2014) }\end{array}$ & $\begin{array}{l}\text { When educational establishments decide to apply BYOD, it means that they } \\
\text { will explicitly implement the policy based on the use of personal technologies } \\
\text { of students }\end{array}$ \\
\hline A. Siani (2017) & $\begin{array}{l}\text { The main idea of BYOD model is that the students will use their personal } \\
\text { devices to support teaching and learning. This idea is opposed to universities } \\
\text { providing mobile technologies to students. }\end{array}$ \\
\hline J. Alden (2013) & $\begin{array}{l}\text { BYOD program seems to be attractive for educational establishments due to } \\
\text { decreased expenses, since it is based on advantages of existing technologies } \\
\text { available for students. }\end{array}$ \\
\hline $\begin{array}{l}\text { S.C. Kong, Y. Y. } \\
\text { Students can use their mobile devices to answer questions with several } \\
\text { variants, which facilitates active feedback in several minutes. The users can } \\
\text { also get access to online applications for learning at any time anywhere using } \\
\text { their preferred devices. }\end{array}$ \\
\hline
\end{tabular}


The research hypothesis is as follows: BYOD is the dominating model in universities, though, there is uncertainty how to arrange BYOD operation.

The research objectives are as follows:

- to analyze opportunities of BYOD,

- to determine issues influencing wider implementation of BYOD, as well as future potentials of the concept.

This article is comprised of the following sections: Introduction, Literature Review, Methods, Results, Discussion, and Conclusion.

\section{Methods}

The formulated target was achieved using a set of theoretical and empirical methods:

- theoretical methods (analysis, synthesis, comparison, generalization) for analysis of publications devoted to the considered problem;

- empirical methods (survey);

- numerical methods (mathematical processing of respondents' results, ranking).

- Surveying was the main research method.

The teachers, IT and network experts from Russian universities participated in the online surveying. Responses from 52 universities were obtained. The results demonstrated some variants of BYOD use, as well as future trends and opportunities.

All surveyed participants were informed about the aim of the survey and about the intention of the researchers to publish the results in generalized form.

\section{Results}

The survey demonstrates wide acceptance of at least certain BYOD level in all universities. Less than $15 \%$ of universities completely banned BYOD, requesting from students, teachers, and staff to access the university network using devices provided by the university (computer classes). $72 \%$ of the surveyed informed that students could use personal devices in the university network. Implementation was applied more widely in the universities where BYOD was initiated (see Table 2).

Table (2): Do you presently allow students/teachers/staff to use personal mobile devices in your university network?

\begin{tabular}{|l|l|l|}
\hline No. & Responses & $\% *$ \\
\hline 1 & Yes, teachers can use personal devices to access the university network & $75.5 \%$ \\
\hline 2 & Yes, students can use personal devices to access the university network & $72.0 \%$ \\
\hline 3 & $\begin{array}{l}\text { Yes, all staff and contractors can use personal devices to access the university } \\
\text { network }\end{array}$ & $57.5 \%$ \\
\hline 4 & $\begin{array}{l}\text { No, students/teachers/staff can get access to the university network only from } \\
\text { devices provided by the university }\end{array}$ & $14 \%$ \\
\hline
\end{tabular}

Remark: Based on results of online survey

The most popular response for the question about the use of personal devices in the universities was: for personal purposes of teachers and students (78\%), followed by: the 
students used their devices to execute class assignments (72\%). These results were expected, since these targets were always achieved using personal devices.

However, one of the most interesting results of this survey was that more than one half $(52 \%)$ of the respondents informed that the personal devices were integrated into learning process. It evidences that BYOD allows to arrange a classroom of the 21 st century, new era in education, where participants use their personal mobile devices for new methods of learning, teaching and cooperation (Table 3). In the nearest future this will be the area of very interesting events, since the teachers introduce new methods of students' involvement. Probably, we will see new building designs, where conventional classrooms and lecture rooms are replaced with interactive educational environment, which allows students and teachers to communicate more efficiently using innovative methods.

Table (3): In what way are personal devices used in your university?

\begin{tabular}{|l|l|l|}
\hline No. & Responses & $\%^{*}$ \\
\hline 1 & The teachers mainly use them to trace assignments and marks & $38.6 \%$ \\
\hline 2 & The students mostly use them for class assignments & $72.0 \%$ \\
\hline 3 & The devices are integrated into learning process & $52.1 \%$ \\
\hline 4 & Personal use & $78 \%$ \\
\hline
\end{tabular}

Remark: Based on results of online survey

According to the surveyed, when hundreds or thousands of students are gathered in the university, quite often with several personal devices, it creates new problems for IT departments responsible for secure connection of users and devices to the network.

More than one half $(56 \%)$ of the respondents declared that their establishments used Network Access Control (NAC) to facilitate automatic access to internal university network in accordance with predefined policies. This evidences wide acceptance of the fact that NAC can provide secure access control for numerous users and devices, making life easier for the IT personnel.

Only $16.7 \%$ of respondents informed that the user devices were registered and connected by IT department manually, which evidences that most universities (and their IT staff) consider such approach as inefficient. However, more than one quarter (27\%) of the respondents informed that they allowed open access for any person. It means that they used BYOD only for Internet access or did not pay attention to security, allowing unknown devices and users to inter into the internal network (Table 4).

Table (4): How do you allow at present to connect personal devices to the network?

\begin{tabular}{|l|l|l|}
\hline No. & Responses & $\% *$ \\
\hline 1 & Each device should be manually registered by IT department & $16.7 \%$ \\
\hline 2 & We allow open access to our network for any person without registration & $27.3 \%$ \\
\hline 3 & $\begin{array}{l}\text { We allow access to the network using self-registration and automation of } \\
\text { BYOD }\end{array}$ & $56.0 \%$ \\
\hline
\end{tabular}

Remark: Based on results of online survey

The software for NAC plays key role in BYOD, providing automatic visibility of the network and access control on the basis of policies, which could be hardly managed manually by IT departments. The result is the opportunity of secure management of connected personal devices in wide scale with minimum load on IT staff.

The NAC technology can identify any device and user getting access to the network so that to be sure that only authorized users and approved devices can be connected to obtain only 
the required data. The access can be defined by user role (student, teacher, guest, etc.), device type, location, day time, and combinations of these criteria.

Herewith, more than $60 \%$ of the respondents stated that their university provided access based on the user role (student or teacher, as a rule). However, the response to the question concerning the network access depending on the type of user device was mostly negative (more than $80 \%$ ) (Table 5).

Table (5): Is the access to the network provided on the basis of user role depending on user device type?

\begin{tabular}{|l|l|l|}
\hline No. & Responses & $\% *$ \\
\hline 1 & No, all have the same level of access to the network & $38.9 \%$ \\
\hline 2 & Yes, we provide access depending of specific role of user in the university & $61.1 \%$ \\
\hline 3 & No, we take into account the device type upon giving access & $80.7 \%$ \\
\hline 4 & Yes, we provide access depending on the device type & $19.3 \%$ \\
\hline
\end{tabular}

Remark: Based on results of online survey

Such mismatching between these two policies could be, probably, attributed to the fact that the existing control system of Wi-Fi university network allows to perform preparation only for user role and not because they do not want to perform preparation regarding the device type. However, without access control by the user role and by the devices, the situation is not complete. When only role access is available, the user can get access to the same network resources using any device, even if it does not comply with the security policies or is just not required in the network. It can be exemplified by the fact that it would be incorrect to register play station, even when the user, owning this station, has a valid account.

The role and hardware preparation are used in combination so that to guarantee that only authorized users with approved devices get access to certain network resources. Depending on the security policy, the users can get one level of access using a device belonging to the university and another level of access using a personal device. Modern NAC system can provide such opportunities.

Only few respondents (18\%) stated that their establishment never updated its BYOD policy. Most respondents (38\%) informed that they updated their policy while implementing new technologies in the university. This approach seems to be reasonable; however, these are not the only modifications, which can influence network performance under the conditions of BYOD (Table 6).

Table (6): How often do you update your BYOD policy?

\begin{tabular}{|l|l|l|}
\hline No. & Responses & $\% *$ \\
\hline 1 & With implementation of new technologies into the network & $38.2 \%$ \\
\hline 2 & Once per year & $24.3 \%$ \\
\hline 3 & Never & $18 \%$ \\
\hline 4 & Other & $15.5 \%$ \\
\hline
\end{tabular}

Remark: Based on results of online survey

Numerous networks are exposed to continuous modifications, including changes of proxy servers, configuration, etc. In this dynamic environment, the BYOD policy can become rapidly outdated. Then the access could be either too restricted (users will not be able to obtain authorized resources) or too open and unsafe (allowing access for users and devices to unauthorized data). Due to these reasons the BYOD best practice dictates that universities should review their BYOD policy at least two times per year and update it when required.

\section{Discussion}


The survey results finally disclose two key conclusions about the state of BYOD in higher education:

1. There are convincing evidences that BYOD is a dominating model in universities. Transfer of technology to students transforms educational experience. BYOD stimulates transfer of the teachers from conventional teaching based on lectures to new models of learning, teaching, and cooperation. According to N. Stutsman (2013), universities have been at the front line of BYOD trend for many years and in many regards provide roadmap for corporations, which only now begin to provide freedom for their employees to select devices. Instead of resistance against this revolution in education, the research results demonstrate that more and more universities adopt this model.

2. There is significant uncertainty concerning the arrangement of BYOD operation. The survey has detected some doubtful methods of security provision as well as possible erroneous presentations about correct method of security provision, when the students use their personal devices in universities. Not all companies realized the importance of transparency of both users and devices getting access to network, or measures of access control, when thousands of various users and devices tried to join the university network. These are the issues to be solved by universities, if their BYOD initiative is successful.

Whether this is a classroom or dormitory, the BYOD process should be automatic, as well as capable to provide access control of any scale (Davis et al., 2013). For students, teachers, and other users it means simple access, so that they are not concerned about getting access to network. For IT personnel it means opportunity to identify each user and device trying to access network with detailed access control, in order to be sure that users acquire specific resources they need, when and where they need, while preventing access to unauthorized resources. At present, the technologies are available, which can solve these problems so that universities could participate in modifications covering education (Miller et al., 2012).

The surveyed experts recommend the following actions upon BYOD implementation:

1. Detailed analysis of transparency and security of university network.

- To what extent are you aware of who and what is connected to the network?

- Can you detect the types of connected end devices and who uses these devices for network connections?

2. Develop or update your own BYOD policy.

- It should be decided, which devices will be supported (tablets, smartphones, etc.).

- It should be determined, which OS will be supported and what software will be required (and their versions). At least one free antivirus program should be allowed, if possible.

- It should be decided, whether to prohibit or restrict any specific applications (for instance, Peer-2-Peer music sharing).

- Various role-based access policies should be determined, required for teachers, staff, and students.

- Determination of restrictive policy, such as isolation or restricted access. 
- Configure remote registration so that the students are able to register their devices before leaving home.

3. Stepwise integration:

- Start from problematic areas with high risk.

- Expand them onto other areas.

4. Provide solution for guests.

- Make guest access easy for search and connection.

- Restrict the guest access (network and bandwidth), otherwise guest networks can be congested.

According to one of the surveyed, one of the most important issues to be remembered is that it is impossible to instantly determine the security risks and demands of students/teachers. BYOD is a continuous process, during which it is necessary to continuously check changing demands of users and to respectively modify the applied policy (Butterman, 2012). The use of correct engineering solution is a key factor in provision of relevance of BYOD policy and automatic control of access to network.

\section{Conclusion}

Currently there is a trend among university students and teachers to use their own notebooks, smartphones, and tablets as a resource to improve their learning experience. Now, when BYOD becomes an independent concept, it is important for educational institutions to understand what should be done when they decide to create their own BYOD network.

The survey results have allowed to conclude as follows:

1. BYOD is widely accepted in universities.

2. Gadgets used by students in universities are highly versatile: from conventional laptops to various smartphones and tablets.

3. The devices are intended not only for personal use; they are more and more often integrated into learning process. In the nearest future this trend will attract high attention, since the teachers use personal mobile devices within classrooms and other learning initiatives.

4. Security remains the major concern of many establishments. The survey also detected proves of doubtful methods of security provision, which were implemented creating network vulnerabilities for numerous respondents.

Therefore, the research hypothesis has been confirmed that BYOD is a dominating model in universities; however, there exists significant uncertainty about arrangement of BYOD operation.

\section{References}

Adhikari, J., Mathrani, A., Scogings, C. (2016). Bring Your Own Devices classroom: Exploring the issue of digital divide in the teaching and learning contexts. Interactive Technology and Smart Education, 13(4): 323-343. 
Adhikari, J., Parsons, D., Mathrani, A. (2012). Bridging Digital Divides in the Learning Process: Challenges and Implications of Integrating ICTs, in: M. Specht, M. Sharples, J. Multisilta (eds.), Proceedings of the 11th International Conference on Mobile and Contextual Learning, mLearn 2012, October 16-18, 2012, Helsinki, Finland, pp. 224-227.

Afreen, R. (2014). Bring your own device (BYOD) in higher education: opportunities and challenges. International Journal of Emerging Trends \& Technology in Computer Science, 3(1): 233-236.

Alden, J. (2013). Accommodating mobile learning in college programs. Journal of Asynchronous Learning Networks, 17(1): 109-122.

Burns, S.M., Lohenry, K. (2010). Cellular phone use in class: Implications for teaching and learning a pilot study. College Student Journal, 44(3): 805-810.

Butterman, E. (2012). Planning for BYOD. Scholastic Administrator, 12(1): 55-57.

Cochrane, T., Antonczak, L., Keegan, H., Narayan, V. (2014). Riding the wave of BYOD: developing a framework for creative pedagogies. Research in Learning Technology, 22(1): 24637. https://doi.org/10.3402/rlt.v22.24637

Cristol, D., Gimbert, B. (2013). Academic Achievement in BYOD Classrooms. QScience Proceedings, 3: 15. https://doi.org/10.5339/qproc.2013.mlearn.15

Davis, N., Eickelmann, B., Zaka, P. (2013). Restructuring of educational systems in the digital age from a co-evolutionary perspective. Journal of Computer Assisted Learning, 29(5): 438-450.

Dyganova, E.A., Yavgildina, Z.M. (2020). Development of Student Musician's Methodological Competence in Practice-Oriented University Environment. Utopía y Praxis Latinoamericana, 5(Extra 5): 113-125.

Efremov, A.A., Sekerin, V.D., Gorokhova, A.E., Slepov, V.A. (2020). Formation of Competencies in Higher Education by Bachelors and Masters. Utopía y Praxis Latinoamericana, 5(Extra 5): 215-220.

French, A.M., Guo, C., Shim, J.P. (2014). Current Status, Issues, and Future of Bring Your Own Device (BYOD). Communications of the Association for Information Systems, 35(10): 191-197.

Gasparian, M.S., Kiseleva, I.A., Chernysheva, E.N., Androshina, I.S. (2020). Internet business modeling: development of information infrastructure, technologies, and models. COMPUSOFT, An international journal of advanced computer technology, 9(6): 3705-3713.

Golubeva, T.I., Ulanova, K.L., Kurenkova, E.A., Kuprina, N.K., Shvetsova, O.Yu., Dmitriyev, V.A. (2020). Video Conferencing and Webinars: Integration of Online Tools in Traditional Forms of Educational and Scientific Activities. International Journal of Advanced Trends in Computer Science and Engineering, 9(4): 4235-4240.

Ivanova, O.E., Abrashkin, M.S., Grishina, V.T., Zakharenko, I.K. (2020). Modification of the financial security database in Russian industrial organizations. Revista Inclusiones, 7(Especial): 540-556.

Johnson, D. (2012). On board with BYOD. Educational Leadership, 70(2): 84-85.

Kinash, S., Brand, J., Mathew, T. (2012). Challenging mobile learning discourse through research: Student perceptions of Blackboard Mobile Learn and iPads. Australasian Journal of Educational Technology, 28(4): 639-655.

Kobus, M.B.W., Rietveld, P., Van Ommeren, J.N. (2013). Ownership versus on-campus use of mobile IT devices by university students. Computers \& Education, 68: 29-41.

Kong, S.C., Song, Y. (2015). An experience of personalized learning hub initiative embedding BYOD for reflective engagement in higher education. Computers \& Education, 88: 227-240.

Lundin, J., Lymer, G., Holmquist, L.E., Brown, B., Rost, M. (2010). Integrating students' mobile technology in higher education. International Journal of Mobile Learning and Organisation, 4(1): 1-14.

Miller, K., Voas, J., Hurlburt, G. (2012). BYOD: Security and Privacy Considerations. IT Professional, 14(5): 53-55. 
Parsons, D., Adhikar, J. (2016). Bring Your Own Device to Secondary School: The Perceptions of Teachers, Students and Parents. Electronic Journal of e-Learning, 14(1): 66-80.

Ramazanova, D., Togaibayeva, A., Turebayeva, K., Yessengulova, M., Kartbayeva, Zh., Imzharova, Z. (2020). Religious approach to the problem of education in V.V. Zenkovsky's Orthodox pedagogy. European Journal of Science and Theology, 16(6): 27-36.

Sánchez, S.P., López-Belmonte, J., Moreno-Guerrero, A.-J., Reche, J.M.S., Cabrera, A.F. (2020). Effect of Bring-Your-Own-Device Program on Flipped Learning in Higher Education Students. Sustainability, 12: 3729. https://doi.org/10.3390/su12093729

Siani, A. (2017). BYOD strategies in higher education: current knowledge, students' perspectives, and challenges. New Directions in the Teaching of Physical Sciences, 12(1): 1-11. https://doi.org/10.29311/ndtps.v0i12.824

Stutsman, N. (2013). BYOD: one year later. Technology and Learning, 33(7): 36-39.

Thomson, G. (2012). BYOD: Enabling the chaos. Network Security, 2: 5-8.

Zueva, F.A., Levina, S.G., Manzhukova, L.F., Likhodumova, I.N., Kilmasova, I.A. (2020). Approaches to the realization of technologies of coordinated formation of students' professional and flexible competencies in the process of professional training. Revista Inclusiones, 7(Especial): 11-18. 